were greased with "the presence of a fatty film", one of their translated papers pointed out. Less explicit was the source of the grease. Only after years of struggling with various lubricants did the Western researchers realize that one member of the Russian group would sometimes run the thread across the bridge of his nose or behind his ear. With the right amount of human 'flossing' (and the right human), the Western scientists managed to get similar results.

The thread greasing is an example of tacit knowledge: know-how that can be passed on only through direct contact, and not by written or verbal instruction. How to ride a bicycle is a classic case. How to make an atomic bomb is a less-well-known example: all the instructions to build a nuclear weapon may be there on the Internet, but the 'been there, done that' personal experience is not. Indeed, security analysts have suggested that the lack of active testing and consequent erosion of nuclear-weapon tacit knowledge is leading to the "uninvention" of the bomb, and reduced credibility of the nuclear deterrent.

In a paper published this month in the journal Science and Public Policy, researchers in the United Kingdom suggest that a reverse process is under way when it comes to biology and biological weapons (J. Revill and C. Jefferson Sci. Public Policy 41, 597-610; 2014). Access to tacit knowledge in the life sciences is not dwindling but proliferating, argue James Revill and Catherine Jefferson. As secrets are shared, chiefly through advances in information and communications technology, tacit knowledge becomes explicit and barriers are demolished. And it is worth considering, they point out, what those barriers have held back. Many attempts have been made to manufacture deadly ricin, for example, probably based on Internet recipes, but most fail to truly weaponize the material by not milling it to the necessary particle size.

"Even where optimised weaponisation is not the strategic goal," the authors write, "tacit knowledge may be an important limiting factor in the ability of unskilled actors to exploit advances in [science and technology], which has important implications for the way in which threat is assessed." Policy-makers who try to proscribe the

development of biological weapons should first gain a better idea of what is scientifically possible and what is not, they suggest, and a sense of how that is changing.

What has any of this to do with the work of a regular bench scientist? Quite a lot, actually. As more attention is paid to the 'reproducibility crisis' in science, and journals and funders wrestle with how to make published research findings more robust, tacit knowledge has emerged as both a problem and an opportunity.

In a Comment piece in this journal last year (M. Bissell Nature 503, 333-334; 2013), Mina Bissell warned that the push to replicate findings could unfairly malign research (and researchers) that - just

"Knowledge has never been more fluid - a good thing, science traditionally argues."

like measuring sapphire quality - relies on tacit-knowledge techniques that are better learnt than studied. The Journal of Visualized Experiments already aims to narrow the gap between tacit and explicit knowledge by requiring scientists to video their techniques, and so show colleagues how to conduct procedures, rather than simply telling them.

There are known unknowns and unknown unknowns, as former US defence secretary Donald Rumsfeld clumsily explained. Some tacit knowledge is deliberately withheld, and some journal methods sections offer insufficient space for elaboration. Those are the known unknowns and are most easily addressed. The tacit knowledge that is harder to pass on is the nugget of information that neither the teacher nor the pupil realized was important: the varnish on the Stradivarius violin; the greasing of the thread behind the ear.

The trend in science is towards greater openness and data sharing. Communication is instant and in real time; knowledge has never been more fluid. Science traditionally argues that this is a good thing. There is no inherently good or bad technology, goes the mantra, only good and bad applications. Is the same true for all forms of knowledge? One way or another, we could be poised to find out.

\section{Holy cows}

\section{A mass beaching of walruses in Alaska is a sign of things to come.}

$\mathrm{F}$ or more than a century the central attraction of the Horniman Museum in London has been a too-large stuffed walrus. Victorian taxidermists, the story goes, had never seen a live walrus, so they simply kept filling the floppy hide until the creature seemed to fit its skin. The bloated specimen spends its days looking down on visitors with an erect and noble posture that it never held in life.

Compared to the photogenic polar bear, the walrus, even one as smoothed for the camera as the Horniman's, makes an unlikely poster species for climate change. But cram the creatures together - 35,000 of them - on a remote Arctic beach, and impose a no-fly zone above to prevent the carnage of a stampede, and it is tempting to see them as the natural world's latest distress beacon to warn of the creeping chaos of global warming.

In the last week, environmental campaigners have cried that the mass walrus beaching in Alaska, first spotted last month, is another clear signal of our warming world. Climate-change sceptics insist that the event is nothing unusual, and have dug out records of previous mass walrus 'haul-outs' to support their case. Delighted by the novelty (images of melting glaciers are so 2009), much of the media has discussed the story, and tried hard to work in a Beatles song reference.

There is a simple way to tell this tale. Walruses spend much of their time out of the water, especially when they are rearing young. They prefer to perch on floating sea ice, which gives them access to the seabed, where most of their food lives. As sea ice retreats north — and this year provided the sixth-lowest extent of summer Arctic ice on record - more walruses have to haul themselves onto the coast. Since 2000, increasing numbers of Pacific walruses (the Atlantic population is less affected) have been forced onto the beaches around the Chukchi Sea; in October 2010, scientists counted a gathering of 120,000 at Cape Serdtse-Kamen in Russia.

Walrus haul-outs on the coast tend to be dominated by adult males. The current event features substantial numbers of mothers and young, which makes it more worrying. A walrus stampede might sound unlikely, but it is a genuine risk. Spooked animals rush to the water and trample anything in their path. The demographics also suggest that something out of the ordinary is going on: female walruses usually recognize the risks of mass haul-outs, and leave the bulls to it.

The link between increased walrus haul-outs on Arctic beaches and the decreased availability of sea ice is clear-cut. The link to climate change is less so, at least in the short term. Sea-ice cover fluctuates with wind and currents from year to year, and the key for walruses is the position of the ice as much as its extent. They need ice over the continental shelf so that they can both rest and feed. In 2008, when remnant ice remained in the Chukchi Sea in the shallow waters of the shelf, walruses did not come ashore in significant numbers.

Whether or not this particular haul-out of walruses in Alaska is a result of climate change is ultimately a moot point. Annual peaks and troughs - of animal movement and ice measurements - are symbolic, but the long-term trend is clear: the Arctic is warming, its ice $\rightarrow$ NATURE.COM To comment online, click on Editorials at: go.nature.com/xhunqv is melting and the walrus's traditional habitat is disappearing. The walruses of the Pacific Arctic face an uncertain future. They might be able to move, they might be able to adapt. Or they might be stuffed. 